DOI:10.17951/h.2020.54.4.41-54

\begin{tabular}{lcc}
\hline \multicolumn{1}{c}{ A N N A L E S } \\
UNIVERSITATIS & MARIAE CURIE-SKŁODOWSKA \\
LUBLIN - POLONIA & SECTIOH H \\
VOL. LIV, 4 & \\
\hline
\end{tabular}

\author{
JERZY GAJDKA \\ jerzy.gajdka@uni.lodz.pl \\ University of Lodz. Faculty of Economics and Sociology \\ 3/5 Polskiej Organizacji Wojskowej St., 90-255 Lodz, Poland \\ ORCID ID: https://orcid.org/0000-0003-1870-3129

\section{PIOTR PIETRASZEWSKI} \\ piotr.pietraszewski@uni.lodz.pl \\ University of Lodz. Faculty of Economics and Sociology \\ 3/5 Polskiej Organizacji Wojskowej St., 90-255 Lodz, Poland \\ ORCID ID: https://orcid.org/0000-0002-0589-0327
}

\title{
Output and Expected Returns in Central and Eastern European Countries
}

Keywords: stock return predictability; GDP; industrial production; CEE countries

JEL: F30; G15

How to quote this paper: Gajdka, J., \& Pietraszewski, P. (2020). Output and Expected Returns in Central and Eastern European Countries. Annales Universitatis Mariae Curie-Skłodowska, sectio HOeconomia, Vol. 54, No. 4.

\footnotetext{
Abstract

Theoretical background: Although some controversy remains, some aspects of the predictability of aggregate stock market returns in the United States and other industrialized countries appear to be relatively well established. Intertemporal asset pricing models based on the paradigm of investor rationality and market efficiency imply that various macro variables describing the state of the economy may forecast future returns on the aggregate stock market.
} 
Purpose of the article: The aim of the article is to present the results of a preliminary study which set out to determine whether the ratio of the stock index to the aggregate output in the economy and future rates of return in the aggregate stock markets in Central and Eastern Europe are significantly related to each other over different time horizons.

Research methods: Heteroskedasticity and autocorrelation-consistent estimators with a small sample degrees of freedom adjustment were used in regressions to track overlapping data problem and small sample bias.

Main findings: The analysis of the key market indices has shown that they explain much of the variation in the long-horizon future cumulative returns, as well as in cumulative excess returns.

\section{Introduction}

Investors have always been seeking ways to forecast stock returns. The standard version of the efficient market theory states that it is not possible unless a major malfunction in the market mechanism occurs. However, a growing body of empirical evidence in support of the thesis that stock returns can be predicted from various market valuation indicators and macroeconomic variables has prompted the finance theorists to abandon the belief in this simplified market behaviour. The predictability of stock returns began to refer to changes in the expected rate of return (used as a discount rate in fundamental valuations), which are supposed to reflect the rational responses of economic entities to changing investment opportunities, probably driven by cyclical fluctuations in risk aversion. As a result, the predictability of stock returns been included in the main asset valuation models (e.g. Campbell \& Cochrane, 1999; Bansal \& Yaron, 2004) and is now considered to be in line with the efficient market theory. An alternative explanation is that markets respond to information that in an efficient market should not cause any price movements. Behavioural finance offers numerous examples of market inefficiencies and many explanations of why they happen. It is not unusual for stock market investors to behave irrationally, to use various heuristics for decision making, to follow emotions, etc. As a result, there are frequent periods when the stock market overreacts or underreacts to new data, which are followed by periods of correction.

The predictability of stock returns in the US and other highly developed countries has been examined using various market ratios and macro variables in numerous studies. Most of them have concluded that returns, mainly the long-term ones, are partly predictable. Fama and French (1988), Campbel and Shiller (2001), Robertson and Wright (2006), Domian and Reichestein (2009) as well as many others have presented evidence that the predictability of returns increases with time horizon. According to Shiller (2014), why the short-term forecast ability of asset prices is practically unlikely is easy to understand; if forecasting the next day's returns were possible, people would easily get rich by trading on these forecasts.

Evidence in support of stock return predictability is usually derived from market aggregates (indexes) rather than the shares of individual companies. However, the results of this research are also of practical importance from the investors' point of 
view. The passive style of investment fund management (involving investments in broad market portfolios) has been popular in the world for a long time. It is also noteworthy that many countries, including those in Central and Eastern Europe (CEE), encourage long-term savings in pension funds, which are usually invested in broad market portfolios.

Investors generally seek simple forecasting methods making use of market indicators showing how share prices relate to various fundamental (accounting) variables. The results of investigations into widely used ratios such as dividend yield or price-to-earnings and price-to-book value are inconclusive. Some of the ratios have been demonstrated to have predictive power for stock returns (see, e.g. Fama \& French, 1988; Campbell \& Shiller, 2001; Trevino \& Robertson, 2002; Cochrane, 2007; Sekuła, 2016; Indrayono, 2019), while others have been proven unreliable (e.g. Ang \& Bekaert, 2007; Goyal \& Welch, 2003).

Numerous studies and empirical evidence point out that in forecasting stock returns the macroeconomic, business-cycle related variables can also be useful (see the review in Cochrane, 2011). According to the studies, the discount rate used in asset valuation varies with the business cycle. This article focuses on presenting the results of a preliminary study which sought to determine whether in the aggregate stock markets in CEE countries the ratio of the index level to the aggregate output in the economy and future rates of return on the indices were significantly related to each other over different time horizons. The intuitive rationale for the study was the assumption that since financial ratios based on stock prices and company fundamentals (price to earnings or price to book ratios) can be used as the predictors of stock returns, the ratio between stock prices and aggregated output in the economy should also be able to predict stock index returns. As the measures of output, gross domestic product and industrial production were taken. The study was conducted with the main stock indices from the following countries: Poland, the Czech Republic, Hungary, Slovakia, Slovenia, Lithuania, Latvia, Estonia, Russia, Croatia, Bulgaria, and Romania. A hypothesis was tested that the relation between the current value of a stock market index and the general level of economic activity in the country has a predictive power for future returns and excess returns, especially for longer-term cumulative returns.

\section{Theoretical background and research review}

The theoretical explanation of the relationship between macroeconomic variables and future stock returns is provided within the neoclassical finance framework by models in which the expected returns on assets change as a result of fluctuating risk aversion of rational investors who maximise intertemporal utility functions by deciding how much of their income should go to consumption and investment. The starting point and reference for this type of theory is the so-called Consumption Cap- 
ital Asset Pricing Model (CCAPM), according to which changes in the expected rate of return can be predicted from changes in the levels of aggregate consumption over time. The resulting asset valuation model presented by Cochrane (1991) directly ties differences in the expected returns to changes in aggregate output. It is analogous to the standard consumption-based model, the only difference being that it uses producers and production functions instead of consumers and utility functions. Because the basic versions of the model had a problem explaining the observed scale of price fluctuations in stock markets, they were appropriately extended and modified by authors such as Campbell and Cochrane (1999), Lettau and Ludvigson (2001), Bansal and Yaron (2004) as well as Santos and Veronesi (2006), who explicitly included the predictability of returns by macro variables in the asset valuation models invoking the paradigm of investor rationality and market efficiency. The modified models basically imply the usefulness of various macro variables describing the state of the economy in forecasting future rates of return on the aggregate stock market. There are number of studies which present evidence that stock returns are predictable using macro variables, i.e. Ang and Bekaert (2007), Rapach, Wohar and Rangvid (2005) Lettau and Ludvigson (2001) or Santos and Veronesi (2006).

Rangvid (2006) put forward a formal justification for the possibility of forecasting share rates of return based on the relation between share prices and aggregate output. Using the so-called dynamic Gordon model presented by Campbell and Shiller (1988), which defines the price-dividend ratio in terms of the expected future rates of return and dividend growth rates, and assuming that the non-stationary component of aggregated dividends arises from output, Rangvid justified the existence of a similar relationship for the ratio of the index level to aggregate output through the following formula:

$$
p_{t}-y_{t}=E_{t} \sum_{j=0}^{\infty} \rho^{j}\left(\Delta y_{t+1+j}-r_{t+1+j}\right)+\frac{k}{1-\rho}+v_{t},
$$

where: $\boldsymbol{p}_{\boldsymbol{t}}$ is the log of the period $t$ price of the share (index), $\boldsymbol{P}_{\boldsymbol{t}}, \boldsymbol{y}_{\boldsymbol{t}}=$ is the log of output, $\boldsymbol{r}_{\boldsymbol{t}}=\ln \left(\boldsymbol{P}_{t}\right)-\ln \left(\boldsymbol{P}_{t-1}\right)$ is the log return, $\boldsymbol{k}$ and $\boldsymbol{\rho}$ are the linearization parameters, $\boldsymbol{E}_{t}$ and $\Delta$ are, respectively, the expected value and the difference operators, and $v_{t}$ is a zero-mean stationary disturbance term.

According to this equation, the time variations in the price-output ratio reflect changes in the expected returns and/or the growth rates of output. For example, when share prices are high for a given level of output, investors will tend to pay much for stocks either to avoid declines in the expected future required rates of return or to profit from economic growth. Given that output changes are moderate compared with the volatility of stock returns, one can expect a significant negative relationship between the ratio of an index level to output and future returns on this index. Also, because the summation on the right side of the equation extends to infinity, it can be concluded that the price-output ratio reflects expectations about the long-horizon cumulative returns. 
The ratio of stock market capitalization to GDP, proposed by Warren Buffett, has been commonly used since the Internet bubble at the turn of the century to forecast returns on the aggregate stock market. Originally developed for the US market based on the Wilshire 5000 and GNP, it was subsequently used in other versions and for other markets (Chang \& Pak, 2018). Lleo and Ziemba (2019) have demonstrated that the Buffett ratio was a statistically significant predictor of stock market corrections in the USA in the years 1971-2016 and that it works relatively well in this role against other popular indicators such as the price-to-earnings ratio or the bond-stock earnings yield differential.

\section{Data and research methods}

The main aim of the underlying research was to determine how informative the price-to-output ratios are about the expected returns and excess returns on the stock markets in CEE countries. The study used monthly data series on the levels of stock indexes, including dividend income (in the Total Return version), sourced from Bloomberg. The start month and year of the series, the country, and the index name (in the brackets) were as follows: Poland (WIG) 01.1995, the Czech Republic (PX) 01.1995, Hungary (BUX) 01.1995, Slovakia (SKSM) 01.1995, Slovenia (MXSL) 05.2002, Lithuania (VILSE) 01.2000, Latvia (RIGSE) 01.2000, Estonia (TALSE) 01.1998, Russia (MOEX) 09.1997, Croatia (CROBEX) 06.2002, Bulgaria (SOFIX) 10.2000, and Romania (BET) 09.1997. All series ended in December 2019. Both total logarithmic returns given by the formula $r_{t}=\ln P_{t}-\ln P_{t-1}$, where $P_{t}$ is the index value at the end of period $t$, and excess returns calculated as $e r_{t}=r_{t}-i_{t}$, where $i_{t}$ is the interest rate, were examined. Because the object of analysis was monthly data, calculations were performed on monthly returns and excess returns. The longer-horizon total or excess rates of returns were calculated as the sums of the respective rates in the subperiods. The excess returns were calculated using the data on short-term interest rates obtained from the OECD database; in the case of Croatia, Bulgaria, and Romania that are not OECD countries, the Eurostat data on 3-month average interest rates were used. The relationship between the stock market situation and the level of economic activity was considered as a predictor of future rates of return. To this end, two indicators were constructed, one by dividing the end-of-month value of an index by the previous quarter's value of the gross domestic product (P/GDP), and the other by dividing the index value by the value of industrial production in the previous month (P/IP). The seasonally-adjusted data on countries' GDP and industrial production were obtained from the Eurostat and OECD databases, respectively. As for the non-OECD countries (Croatia, Bulgaria, and Romania), only the GDP data were used. The nominal data were adjusted for inflation with CPI obtained from the OECD database. An exception was the three non-OECD countries, in the case of which the HICP indices obtained from the Eurostat database were deployed. 
The next section presents the preliminary results of an empirical investigation carried out in line with the basic methodology that many authors have used (e.g. Campbell \& Shiller, 2001; Rangvid, 2006; Robertson \& Wright, 2006; Domian \& Reichenstein, 2009; Keimling, 2016). In order to determine whether the price-to-output ratios carry any information about the expected returns and excess returns, the following regression equation was estimated:

$$
\mathrm{x}_{\mathrm{t}, \mathrm{h}}=\alpha+\beta_{\mathrm{h}} \mathrm{z}_{\mathrm{t}}+\mathrm{e}_{\mathrm{t}}
$$

where $z_{t}$ is the natural logarithm of the predictor variable and $x_{t, h}$ denotes both the real $h$-period logarithmic rate of return and the excess return on the index over monthly, quarterly, semi-annual, annual, 3-year, 5-year, and 10-year horizons.

The data used in regressions is sensitive to the "overlapping period" problem. For instance, when annual returns are calculated month by month, 11 out of 12 months are the same months as in the case of the previous one-year return. This leads to the presence of a moving average in the residuals, biases their variance estimator, and causes that the OLS standard errors are incorrect (underestimated) (Hansen \& Hodrick, 1980; Kirby, 1997). The ways of solving the problem have been widely discussed in the literature (e.g. Nelson \& Kim, 1993; Stambaugh, 1999; Harri \& Brorsen, 2009). Various statistical techniques have been proposed to obtain unbiased standard errors and t-statistics, including heteroskedasticity and the autocovariance-consistent estimators using a Newey-West adjustment to correct the estimated standard errors that have gained widespread popularity (Newey \& West, 1987; Hansen \& Hodrick, 1980; Hodrick, 1992). In the study, the $p$-values for the test of the null hypothesis $\mathrm{H} 0-\beta_{\mathrm{h}}=0$ are reported using both Newey-West (NW) (with the Bartlett kernel) and Hansen-Hodrick (HH) (with the truncated-uniform kernel) HAC standard errors adjusted to small-sample bias (by making a small sample degrees of freedom correction).

\section{Results and discussion}

Table 1 presents the results of regression of future cumulative total returns on indices against price to GDP and price to industrial production ratios. 
Pobrane z czasopisma Annales H - Oeconomia http://oeconomia.annales.umcs.pl

Data: 26/04/2023 14:16:36

OUTPUT AND EXPECTED RETURNS IN CENTRAL AND EASTERN EUROPEAN COUNTRIES

Table 1. The regression results for future total returns on indices against P/GDP and P/IP ratios

\begin{tabular}{|c|c|c|c|c|c|c|c|c|}
\hline \multicolumn{2}{|c|}{ Poland (WIG) } & \multirow{2}{*}{$\begin{array}{r}10 \mathrm{Y} \\
0.596\end{array}$} & \multirow{2}{*}{$\begin{array}{r}5 \mathrm{Y} \\
0.733\end{array}$} & \multirow{2}{*}{$\begin{array}{r}3 \mathrm{Y} \\
0.458\end{array}$} & \multirow{2}{*}{$\begin{array}{r}1 \mathrm{Y} \\
0.226\end{array}$} & \multirow{2}{*}{$\begin{array}{r}6 \mathrm{M} \\
0.101\end{array}$} & \multirow{2}{*}{$\begin{array}{r}3 \mathrm{M} \\
0.046\end{array}$} & \multirow{2}{*}{$\frac{1 \mathrm{M}}{0.014}$} \\
\hline $\mathrm{P} / \mathrm{GDP}$ & $\mathrm{R}^{\wedge} 2$ & & & & & & & \\
\hline & coef. & -0.086 & -0.302 & -0.327 & -0.491 & -0.224 & -0.104 & -0.034 \\
\hline & NW & 0 & 0 & 0 & 0 & 0.013 & 0.042 & 0.073 \\
\hline & $\mathrm{HH}$ & 0 & 0 & 0 & 0.014 & 0.064 & 0.093 & 0.105 \\
\hline \multirow[t]{4}{*}{$\mathrm{P} / \mathrm{IP}$} & $\mathrm{R}^{\wedge} 2$ & 0.688 & 0.348 & 0.244 & 0.192 & 0.094 & 0.059 & 0.021 \\
\hline & coef. & -0.088 & -0.186 & -0.212 & -0.394 & -0.188 & -0.103 & -0.036 \\
\hline & NW & 0 & 0 & 0 & 0 & 0.005 & 0.012 & 0.021 \\
\hline & $\mathrm{HH}$ & 0 & 0 & 0 & 0.007 & 0.028 & 0.018 & 0.021 \\
\hline \multicolumn{2}{|c|}{ Czech Republic (PX) } & $10 \mathrm{Y}$ & $5 \mathrm{Y}$ & $3 \mathrm{Y}$ & $1 \mathrm{Y}$ & $6 \mathrm{M}$ & $3 \mathrm{M}$ & $1 \mathrm{M}$ \\
\hline \multirow[t]{4}{*}{ P/GDP } & $\mathrm{R}^{\wedge} 2$ & 0.714 & 0.660 & 0.416 & 0.154 & 0.072 & 0.031 & 0.009 \\
\hline & coef. & -0.107 & -0.287 & -0.302 & -0.338 & -0.157 & -0.069 & -0.021 \\
\hline & NW & 0 & 0 & 0 & 0.003 & 0.029 & 0.061 & 0.094 \\
\hline & $\mathrm{HH}$ & 0 & 0 & 0 & 0.037 & 0.102 & 0.104 & 0.112 \\
\hline \multirow[t]{4}{*}{$\mathrm{P} / \mathrm{IP}$} & $\mathrm{R}^{\wedge} 2$ & 0.866 & 0.426 & 0.255 & 0.097 & 0.042 & 0.018 & 0.005 \\
\hline & coef. & -0.107 & -0.206 & -0.219 & -0.253 & -0.114 & -0.050 & -0.014 \\
\hline & NW & 0 & 0 & 0 & 0.017 & 0.103 & 0.192 & 0.269 \\
\hline & $\mathrm{HH}$ & 0 & 0 & 0.002 & 0.091 & 0.218 & 0.248 & 0.300 \\
\hline \multicolumn{2}{|c|}{ Hungary (BUX) } & $10 \mathrm{Y}$ & $5 \mathrm{Y}$ & $3 \mathrm{Y}$ & $1 \mathrm{Y}$ & $6 \mathrm{M}$ & $3 \mathrm{M}$ & $1 \mathrm{M}$ \\
\hline \multirow[t]{4}{*}{$\mathrm{P} / \mathrm{GDP}$} & $\mathrm{R}^{\wedge} 2$ & 0.530 & 0.628 & 0.638 & 0.403 & 0.19 & 0.091 & 0.028 \\
\hline & coef. & -0.977 & -1.243 & -0.386 & -0.609 & -0.275 & -0.128 & -0.040 \\
\hline & $\mathrm{NW}$ & 0 & 0 & 0 & 0 & 0 & 0 & 0.003 \\
\hline & $\mathrm{HH}$ & 0 & 0 & 0 & 0 & 0 & 0 & 0.003 \\
\hline \multirow[t]{4}{*}{$\mathrm{P} / \mathrm{IP}$} & $\mathrm{R}^{\wedge} 2$ & 0.685 & 0.418 & 0.397 & 0.251 & 0.109 & 0.054 & 0.016 \\
\hline & coef. & -0.818 & -0.703 & -0.208 & -0.312 & -0.134 & -0.063 & -0.020 \\
\hline & NW & 0 & 0 & 0 & 0 & 0 & 0.004 & 0.016 \\
\hline & $\mathrm{HH}$ & 0 & 0 & 0 & 0 & 0.007 & 0.007 & 0.026 \\
\hline \multicolumn{2}{|c|}{ Slovakia (SKSM) } & $10 \mathrm{Y}$ & $5 \mathrm{Y}$ & $3 \mathrm{Y}$ & $1 \mathrm{Y}$ & $6 \mathrm{M}$ & $3 \mathrm{M}$ & $1 \mathrm{M}$ \\
\hline \multirow[t]{4}{*}{$\mathrm{P} / \mathrm{GDP}$} & $\mathrm{R}^{\wedge} 2$ & 0.525 & 0.806 & 0.532 & 0.116 & 0.051 & 0.026 & 0.009 \\
\hline & coef. & -0.069 & -0.317 & -0.346 & -0.226 & -0.093 & -0.041 & -0.012 \\
\hline & NW & 0 & 0 & 0 & 0 & 0.020 & 0.103 & 0.182 \\
\hline & $\mathrm{HH}$ & 0 & 0 & 0 & 0.009 & 0.058 & 0.130 & 0.208 \\
\hline \multirow[t]{4}{*}{$\mathrm{P} / \mathrm{IP}$} & $\mathrm{R}^{\wedge} 2$ & 0.780 & 0.700 & 0.377 & 0.075 & 0.032 & 0.014 & 0.004 \\
\hline & coef. & -0.085 & -0.309 & -0.301 & -0.187 & -0.076 & -0.031 & -0.009 \\
\hline & NW & 0 & 0 & 0 & 0.002 & 0.061 & 0.228 & 0.332 \\
\hline & $\mathrm{HH}$ & 0 & 0 & 0 & 0.026 & 0.145 & 0.294 & 0.394 \\
\hline \multicolumn{2}{|c|}{ Slovenia (MXLS) } & $10 \mathrm{Y}$ & $5 \mathrm{Y}$ & $3 \mathrm{Y}$ & $1 \mathrm{Y}$ & $6 \mathrm{M}$ & $3 \mathrm{M}$ & $1 \mathrm{M}$ \\
\hline \multirow[t]{4}{*}{$\mathrm{P} / \mathrm{GDP}$} & $\mathrm{R}^{\wedge} 2$ & 0.925 & 0.761 & 0.442 & 0.192 & 0.079 & 0.032 & 0.008 \\
\hline & coef. & -0.100 & -0.307 & -0.310 & -0.372 & -0.148 & -0.057 & -0.015 \\
\hline & NW & 0 & 0 & 0 & 0.018 & 0.156 & 0.298 & 0.421 \\
\hline & $\mathrm{HH}$ & 0 & 0 & 0 & 0.088 & 0.306 & 0.440 & 0.544 \\
\hline
\end{tabular}


Pobrane z czasopisma Annales H - Oeconomia http://oeconomia.annales.umcs.pl

Data: 26/04/2023 14:16:36

Cont. Table 1.

\begin{tabular}{|c|c|c|c|c|c|c|c|c|}
\hline \multicolumn{2}{|c|}{ Slovenia (MXLS) } & $10 \mathrm{Y}$ & $5 \mathrm{Y}$ & $3 \mathrm{Y}$ & $1 \mathrm{Y}$ & $6 \mathrm{M}$ & $3 \mathrm{M}$ & $1 \mathrm{M}$ \\
\hline \multirow[t]{4}{*}{$\mathrm{P} / \mathrm{IP}$} & $\mathrm{R}^{\wedge} 2$ & 0.807 & 0.901 & 0.65 & 0.288 & 0.121 & 0.052 & 0.015 \\
\hline & coef. & -0.082 & -0.326 & -0.374 & -0.46 & -0.185 & -0.074 & -0.021 \\
\hline & NW & 0 & 0 & 0 & 0 & 0.051 & 0.149 & 0.236 \\
\hline & $\mathrm{HH}$ & 0 & 0 & 0 & 0.012 & 0.154 & 0.277 & 0.365 \\
\hline \multicolumn{2}{|c|}{ Lithuania (VILSE) } & $10 \mathrm{Y}$ & $5 \mathrm{Y}$ & $3 Y$ & $1 \mathrm{Y}$ & $6 \mathrm{M}$ & $3 \mathrm{M}$ & $1 \mathrm{M}$ \\
\hline \multirow[t]{4}{*}{ P/GDP } & $\mathrm{R}^{\wedge} 2$ & 0.968 & 0.853 & 0.695 & 0.181 & 0.066 & 0.020 & 0.003 \\
\hline & coef. & -0.102 & -0.328 & -0.429 & -0.389 & -0.153 & -0.053 & -0.009 \\
\hline & NW & 0 & 0 & 0 & 0 & 0.034 & 0.218 & 0.547 \\
\hline & $\mathrm{HH}$ & 0 & 0 & 0 & 0.016 & 0.085 & 0.277 & 0.602 \\
\hline \multirow[t]{4}{*}{$\mathrm{P} / \mathrm{IP}$} & $\mathrm{R}^{\wedge} 2$ & 0.868 & 0.752 & 0.657 & 0.197 & 0.081 & 0.034 & 0.009 \\
\hline & coef. & -0.092 & -0.275 & -0.358 & -0.336 & -0.139 & -0.056 & -0.013 \\
\hline & NW & 0 & 0 & 0 & 0.001 & 0.018 & 0.082 & 0.231 \\
\hline & $\mathrm{HH}$ & 0 & 0 & 0 & 0.021 & 0.070 & 0.144 & 0.309 \\
\hline \multicolumn{2}{|c|}{ Latvia (RIGSE) } & $10 \mathrm{Y}$ & $5 \mathrm{Y}$ & $3 \mathrm{Y}$ & $1 \mathrm{Y}$ & $6 \mathrm{M}$ & $3 \mathrm{M}$ & $1 \mathrm{M}$ \\
\hline \multirow[t]{4}{*}{$\mathrm{P} / \mathrm{GDP}$} & $\mathrm{R}^{\wedge} 2$ & 0.934 & 0.471 & 0.283 & 0.039 & 0.010 & 0.001 & 0 \\
\hline & coef. & -0.132 & -0.283 & -0.314 & -0.181 & -0.058 & -0.014 & 0.001 \\
\hline & NW & 0 & 0 & 0 & 0.040 & 0.434 & 0.785 & 0.974 \\
\hline & $\mathrm{HH}$ & 0 & 0 & 0.015 & 0.122 & 0.496 & 0.801 & 0.976 \\
\hline \multirow[t]{4}{*}{$\mathrm{P} / \mathrm{IP}$} & $\mathrm{R}^{\wedge} 2$ & 0.230 & 0.629 & 0.516 & 0.18 & 0.105 & 0.049 & 0.020 \\
\hline & coef. & -0.059 & -0.331 & -0.411 & -0.339 & -0.164 & -0.071 & -0.023 \\
\hline & NW & 0 & 0 & 0 & 0 & 0 & 0.011 & 0.032 \\
\hline & $\mathrm{HH}$ & 0 & 0 & 0 & 0.004 & 0.003 & 0.008 & 0.021 \\
\hline \multicolumn{2}{|c|}{ Estonia (TALSE) } & $10 \mathrm{Y}$ & $5 \mathrm{Y}$ & $3 \mathrm{Y}$ & $1 \mathrm{Y}$ & $6 \mathrm{M}$ & $3 \mathrm{M}$ & $1 \mathrm{M}$ \\
\hline \multirow[t]{4}{*}{$\mathrm{P} / \mathrm{GDP}$} & $\mathrm{R}^{\wedge} 2$ & 0.853 & 0.750 & 0.500 & 0.167 & 0.065 & 0.024 & 0.006 \\
\hline & coef. & -0.097 & -0.292 & -0.341 & -0.367 & -0.157 & -0.063 & -0.017 \\
\hline & NW & 0 & 0 & 0 & 0 & 0.007 & 0.097 & 0.242 \\
\hline & $\mathrm{HH}$ & 0 & 0 & 0 & 0.003 & 0.024 & 0.090 & 0.205 \\
\hline \multirow[t]{4}{*}{$\mathrm{P} / \mathrm{IP}$} & $\mathrm{R}^{\wedge} 2$ & 0.666 & 0.637 & 0.369 & 0.107 & 0.033 & 0.011 & 0.003 \\
\hline & coef. & -0.074 & -0.218 & -0.233 & -0.228 & -0.088 & -0.033 & -0.008 \\
\hline & NW & 0 & 0 & 0 & 0.001 & 0.040 & 0.243 & 0.415 \\
\hline & $\mathrm{HH}$ & 0 & 0 & 0 & 0.018 & 0.077 & 0.198 & 0.276 \\
\hline \multicolumn{2}{|c|}{ Russia (TALSE) } & $10 \mathrm{Y}$ & $5 \mathrm{Y}$ & $3 \mathrm{Y}$ & $1 \mathrm{Y}$ & $6 \mathrm{M}$ & $3 \mathrm{M}$ & $1 \mathrm{M}$ \\
\hline \multirow[t]{4}{*}{$\mathrm{P} / \mathrm{GDP}$} & $\mathrm{R}^{\wedge} 2$ & 0.960 & 0.578 & 0.770 & 0.298 & 0.152 & 0.070 & 0.024 \\
\hline & coef. & -0.072 & -0.150 & -0.418 & -0.538 & -0.273 & -0.119 & -0.034 \\
\hline & NW & 0 & 0 & 0 & 0 & 0.002 & 0.006 & 0.068 \\
\hline & $\mathrm{HH}$ & 0 & 0 & 0 & 0.011 & 0.015 & 0.001 & 0.007 \\
\hline \multirow[t]{4}{*}{$\mathrm{P} / \mathrm{IP}$} & $\mathrm{R}^{\wedge} 2$ & 0.919 & 0.550 & 0.287 & 0.06 & 0.007 & 0.001 & 0 \\
\hline & coef. & -0.064 & -0.010 & -0.096 & -0.105 & -0.029 & -0.008 & 0.0003 \\
\hline & NW & 0 & 0 & 0 & 0.174 & 0.673 & 0.848 & 0.982 \\
\hline & $\mathrm{HH}$ & 0 & 0 & 0.004 & 0.303 & 0.733 & 0.866 & 0.984 \\
\hline
\end{tabular}


Pobrane z czasopisma Annales H - Oeconomia http://oeconomia.annales.umcs.pl Data: 26/04/2023 14:16:36

OUTPUT AND EXPECTED RETURNS IN CENTRAL AND EASTERN EUROPEAN COUNTRIES

Cont. Table 1.

\begin{tabular}{|c|c|c|c|c|c|c|c|c|}
\hline \multicolumn{2}{|c|}{ Croatia (CROBEX) } & \multirow{2}{*}{$\begin{array}{r}10 \mathrm{Y} \\
0.971\end{array}$} & \multirow{2}{*}{$\begin{array}{r}5 \mathrm{Y} \\
0.645\end{array}$} & \multirow{2}{*}{$\begin{array}{r}3 \mathrm{Y} \\
0.509\end{array}$} & \multirow{2}{*}{$\begin{array}{r}1 Y \\
0.201\end{array}$} & \multirow{2}{*}{$\begin{array}{r}6 \mathrm{M} \\
0.089\end{array}$} & \multirow{2}{*}{$\begin{array}{r}3 \mathrm{M} \\
0.033\end{array}$} & \multirow{2}{*}{$\begin{array}{r}1 \mathrm{M} \\
0.008\end{array}$} \\
\hline $\mathrm{P} / \mathrm{GDP}$ & $\mathrm{R}^{\wedge} 2$ & & & & & & & \\
\hline & coef. & -0.103 & -0.254 & -0.367 & -0.427 & -0.190 & -0.073 & -0.019 \\
\hline & NW & 0 & 0 & 0 & 0.037 & 0.140 & 0.263 & 0.381 \\
\hline & $\mathrm{HH}$ & 0 & 0 & 0 & 0.136 & 0.284 & 0.378 & 0.491 \\
\hline \multicolumn{2}{|c|}{ Bulgaria (SOFIX) } & $10 \mathrm{Y}$ & $5 \mathrm{Y}$ & $3 \mathrm{Y}$ & $1 \mathrm{Y}$ & $6 \mathrm{M}$ & $3 \mathrm{M}$ & $1 \mathrm{M}$ \\
\hline \multirow[t]{4}{*}{$\mathrm{P} / \mathrm{GDP}$} & $\mathrm{R}^{\wedge} 2$ & 0.948 & 0.843 & 0.52 & 0.174 & 0.066 & 0.024 & 0.005 \\
\hline & coef. & -0.081 & -0.312 & -0.327 & -0.315 & -0.121 & -0.045 & -0.010 \\
\hline & NW & 0 & 0 & 0 & 0.023 & 0.099 & 0.211 & 0.379 \\
\hline & $\mathrm{HH}$ & 0 & 0 & 0 & 0.109 & 0.225 & 0.299 & 0.412 \\
\hline \multicolumn{2}{|c|}{ Romania (BET) } & $10 \mathrm{Y}$ & $5 \mathrm{Y}$ & $3 \mathrm{Y}$ & $1 \mathrm{Y}$ & $6 \mathrm{M}$ & $3 \mathrm{M}$ & $1 \mathrm{M}$ \\
\hline \multirow[t]{4}{*}{$\mathrm{P} / \mathrm{GDP}$} & $\mathrm{R}^{\wedge} 2$ & 0.798 & 0.744 & 0.566 & 0.293 & 0.161 & 0.083 & 0.031 \\
\hline & coef. & -0.083 & -0.285 & -0.386 & -0.533 & -0.263 & -0.124 & -0.038 \\
\hline & NW & 0 & 0 & 0 & 0 & 0.003 & 0.015 & 0.040 \\
\hline & $\mathrm{HH}$ & 0 & 0 & 0 & 0.011 & 0.026 & 0.031 & 0.049 \\
\hline
\end{tabular}

Source: Authors' own study.

The main feature of the results presented in Table 1 is the predictably negative sign of all regression coefficients. In general, the ability of price-to-GDP and price-to-industrial production ratios to track the volatility of future cumulative returns on indices increases with the time horizon. Compared with the 10-year returns and 5 -year returns, for which the determination coefficients' values are high or very high (in the first case sometimes exceeding 95\% (as for Lithuania, Russia or Croatia for the price-GDP ratio), for the monthly returns the explanatory power of the regressions as measured with $\mathrm{R}^{2}$ never exceeds $3 \%$ and for quarterly returns $10 \%$, but typically these values are much lower. Some exceptions to this general rule are the price-GDP ratio for Poland, Hungary, and Slovakia, and the price-industrial production ratio for Slovenia and Latvia that better explain the variability of 5-year returns than of 10-year returns (the same was observed for the price-GDP ratio and 3-year and 5-year returns in Russia). A similar general pattern emerged after the statistical significance of the studied relationships was taken into account - the significance decreased as the period for which future cumulative returns were calculated grew shorter. For the 10-, 5- and 3-year returns, all relationships were statistically significant, while for the monthly and quarterly returns - only for Hungary, Poland, Romania and Russia (in the last case only for the price-GDP ratio), usually at higher levels of significance ( 0.05 or 0.1$)$. In the case of semi-annual and annual returns, the between-country differences were substantial. 
Pobrane z czasopisma Annales H - Oeconomia http://oeconomia.annales.umcs.pl

Data: 26/04/2023 14:16:36

JERZY GAJDKA, PIOTR PIETRASZEWSKI

Table 2. The regression results for future excess returns on indices against $\mathrm{P} / \mathrm{GDP}$ and $\mathrm{P} / \mathrm{IP}$ ratios

\begin{tabular}{|c|c|c|c|c|c|c|c|c|}
\hline \multicolumn{2}{|c|}{ Poland (WIG) } & $10 \mathrm{Y}$ & $5 \mathrm{Y}$ & $3 \mathrm{Y}$ & $1 Y$ & $6 \mathrm{M}$ & $3 \mathrm{M}$ & $1 \mathrm{M}$ \\
\hline \multirow[t]{4}{*}{$\mathrm{P} / \mathrm{GDP}$} & $\mathrm{R}^{\wedge} 2$ & 0.611 & 0.509 & 0.311 & 0.172 & 0.074 & 0.033 & 0.010 \\
\hline & coef. & -0.825 & -1.400 & -0.893 & -0.448 & -0.201 & -0.091 & -0.028 \\
\hline & NW & 0 & 0 & 0 & 0.003 & 0.032 & 0.083 & 0.130 \\
\hline & $\mathrm{HH}$ & 0 & 0 & 0 & 0.033 & 0.110 & 0.155 & 0.175 \\
\hline \multirow[t]{4}{*}{$\mathrm{P} / \mathrm{IP}$} & $\mathrm{R}^{\wedge} 2$ & 0.263 & 0.123 & 0.088 & 0.115 & 0.052 & 0.035 & 0.014 \\
\hline & coef. & -0.516 & -0.611 & -0.420 & -0.318 & -0.146 & -0.082 & -0.029 \\
\hline & NW & 0.001 & 0.005 & 0.007 & 0.004 & 0.038 & 0.056 & 0.072 \\
\hline & $\mathrm{HH}$ & 0.017 & 0.050 & 0.057 & 0.039 & 0.105 & 0.069 & 0.075 \\
\hline \multicolumn{2}{|c|}{ Czech Republic (PX) } & $10 \mathrm{Y}$ & $5 \mathrm{Y}$ & $3 \mathrm{Y}$ & $1 Y$ & $6 \mathrm{M}$ & $3 \mathrm{M}$ & $1 \mathrm{M}$ \\
\hline \multirow[t]{4}{*}{$\mathrm{P} / \mathrm{GDP}$} & $\mathrm{R}^{\wedge} 2$ & 0.577 & 0.649 & 0.437 & 0.125 & 0.052 & 0.022 & 0.007 \\
\hline & coef. & -0.840 & -1.349 & -0.838 & -0.252 & -0.108 & -0.047 & -0.014 \\
\hline & NW & 0 & 0 & 0 & 0.002 & 0.021 & 0.052 & 0.087 \\
\hline & $\mathrm{HH}$ & 0 & 0 & 0 & 0.029 & 0.082 & 0.082 & 0.075 \\
\hline \multirow[t]{4}{*}{$\mathrm{P} / \mathrm{IP}$} & $\mathrm{R}^{\wedge} 2$ & 0.812 & 0.290 & 0.168 & 0.065 & 0.026 & 0.010 & 0.003 \\
\hline & coef. & -0.922 & -0.899 & -0.564 & -0.210 & -0.091 & -0.038 & -0.011 \\
\hline & NW & 0 & 0 & 0 & 0.053 & 0.200 & 0.316 & 0.416 \\
\hline & $\mathrm{HH}$ & 0 & 0.001 & 0.015 & 0.168 & 0.332 & 0.377 & 0.448 \\
\hline \multicolumn{2}{|c|}{ Hungary (BUX) } & $10 \mathrm{Y}$ & $5 \mathrm{Y}$ & $3 \mathrm{Y}$ & $1 \mathrm{Y}$ & $6 \mathrm{M}$ & $3 \mathrm{M}$ & $1 \mathrm{M}$ \\
\hline \multirow[t]{4}{*}{$\mathrm{P} / \mathrm{GDP}$} & $\mathrm{R}^{\wedge} 2$ & 0.476 & 0.548 & 0.556 & 0.345 & 0.153 & 0.069 & 0.021 \\
\hline & coef. & -0.856 & -1.196 & -1.094 & -0.563 & -0.251 & -0.114 & 0.034 \\
\hline & NW & 0 & 0 & 0 & 0 & 0 & 0.003 & 0.015 \\
\hline & $\mathrm{HH}$ & 0 & 0 & 0 & 0 & 0.001 & 0.004 & 0.016 \\
\hline \multirow[t]{4}{*}{$\mathrm{P} / \mathrm{IP}$} & $\mathrm{R}^{\wedge} 2$ & 0.557 & 0.308 & 0.301 & 0.194 & 0.075 & 0.037 & 0.011 \\
\hline & coef. & -0.677 & -0.616 & -0.549 & -0.273 & -0.112 & -0.053 & -0.016 \\
\hline & NW & 0 & 0 & 0 & 0 & 0.007 & 0.024 & 0.054 \\
\hline & $\mathrm{HH}$ & 0 & 0 & 0 & 0 & 0.030 & 0.030 & 0.072 \\
\hline \multicolumn{2}{|c|}{ Slovakia (SKSM) } & $10 \mathrm{Y}$ & $5 \mathrm{Y}$ & $3 \mathrm{Y}$ & $1 \mathrm{Y}$ & $6 \mathrm{M}$ & $3 \mathrm{M}$ & $1 \mathrm{M}$ \\
\hline \multirow[t]{4}{*}{$\mathrm{P} / \mathrm{GDP}$} & $\mathrm{R}^{\wedge} 2$ & 0.78 & 0.815 & 0.543 & 0.156 & 0.061 & 0.030 & 0.010 \\
\hline & coef. & -0.835 & -1.709 & -1.161 & -0.286 & -0.108 & -0.046 & -0.013 \\
\hline & NW & 0 & 0 & 0 & 0 & 0.015 & 0.086 & 0.166 \\
\hline & $\mathrm{HH}$ & 0 & 0 & 0 & 0.004 & 0.058 & 0.123 & 0.196 \\
\hline \multirow[t]{4}{*}{$\mathrm{P} / \mathrm{IP}$} & $\mathrm{R}^{\wedge} 2$ & 0.860 & 0.665 & 0.353 & 0.086 & 0.031 & 0.013 & 0.004 \\
\hline & coef. & -0.866 & -1.577 & -0.957 & -0.218 & -0.079 & -0.031 & -0.008 \\
\hline & NW & 0 & 0 & 0 & 0.001 & 0.065 & 0.228 & 0.360 \\
\hline & $\mathrm{HH}$ & 0 & 0 & 0 & 0.026 & 0.160 & 0.314 & 0.434 \\
\hline \multicolumn{2}{|c|}{ Slovenia (MXLS) } & $10 \mathrm{Y}$ & $5 \mathrm{Y}$ & $3 \mathrm{Y}$ & $1 \mathrm{Y}$ & $6 \mathrm{M}$ & $3 \mathrm{M}$ & $1 \mathrm{M}$ \\
\hline \multirow[t]{4}{*}{$\mathrm{P} / \mathrm{GDP}$} & $\mathrm{R}^{\wedge} 2$ & 0.885 & 0.791 & 0.471 & 0.204 & 0.084 & 0.034 & 0.009 \\
\hline & coef. & -0.941 & -1.520 & -0.939 & -0.384 & -0.153 & -0.059 & -0.015 \\
\hline & NW & 0 & 0 & 0 & 0.017 & 0.151 & 0.288 & 0.412 \\
\hline & $\mathrm{HH}$ & 0 & 0 & 0 & 0.085 & 0.300 & 0.430 & 0.537 \\
\hline
\end{tabular}


Pobrane z czasopisma Annales $\mathrm{H}$ - Oeconomia http://oeconomia.annales.umcs.pl

Data: 26/04/2023 14:16:36

OUTPUT AND EXPECTED RETURNS IN CENTRAL AND EASTERN EUROPEAN COUNTRIES

Cont. Table 2.

\begin{tabular}{|c|c|c|c|c|c|c|c|c|}
\hline \multicolumn{2}{|c|}{ Slovenia (MXLS) } & $10 \mathrm{Y}$ & $5 \mathrm{Y}$ & $3 \mathrm{Y}$ & $1 \mathrm{Y}$ & $6 \mathrm{M}$ & $3 \mathrm{M}$ & $1 \mathrm{M}$ \\
\hline \multirow[t]{4}{*}{$\mathrm{P} / \mathrm{IP}$} & $\mathrm{R}^{\wedge} 2$ & 0.724 & 0.901 & 0.656 & 0.291 & 0.119 & 0.050 & 0.014 \\
\hline & coef. & -0.755 & -1.583 & -1.102 & -0.463 & -0.185 & -0.073 & -0.020 \\
\hline & NW & 0 & 0 & 0 & 0.001 & 0.057 & 0.158 & 0.252 \\
\hline & $\mathrm{HH}$ & 0 & 0 & 0 & 0.015 & 0.164 & 0.287 & 0.382 \\
\hline \multicolumn{2}{|c|}{ Lithuania (VILSE) } & $10 \mathrm{Y}$ & $5 \mathrm{Y}$ & $3 \mathrm{Y}$ & $1 \mathrm{Y}$ & $6 \mathrm{M}$ & $3 \mathrm{M}$ & $1 \mathrm{M}$ \\
\hline \multirow[t]{4}{*}{$\mathrm{P} / \mathrm{GDP}$} & $\mathrm{R}^{\wedge} 2$ & 0.954 & 0.851 & 0.635 & 0.130 & 0.040 & 0.009 & 0.0004 \\
\hline & coef. & -0.965 & -1.568 & -1.184 & -0.322 & -0.117 & -0.035 & -0.003 \\
\hline & NW & 0 & 0 & 0 & 0.005 & 0.099 & 0.402 & 0.823 \\
\hline & $\mathrm{HH}$ & 0 & 0 & 0 & 0.045 & 0.177 & 0.459 & 0.846 \\
\hline \multirow[t]{4}{*}{$\mathrm{P} / \mathrm{IP}$} & $\mathrm{R}^{\wedge} 2$ & 0.826 & 0.737 & 0.586 & 0.143 & 0.051 & 0.019 & 0.003 \\
\hline & coef. & -0.853 & -1.298 & -0.977 & -0.281 & -0.108 & -0.04 & -0.008 \\
\hline & NW & 0 & 0 & 0 & 0.006 & 0.063 & 0.200 & 0.459 \\
\hline & $\mathrm{HH}$ & 0 & 0 & 0 & 0.056 & 0.152 & 0.056 & 0.528 \\
\hline \multicolumn{2}{|c|}{ Latvia (RIGSE) } & $10 \mathrm{Y}$ & $5 \mathrm{Y}$ & $3 \mathrm{Y}$ & $1 \mathrm{Y}$ & $6 \mathrm{M}$ & $3 \mathrm{M}$ & $1 \mathrm{M}$ \\
\hline \multirow[t]{4}{*}{$\mathrm{P} / \mathrm{GDP}$} & $\mathrm{R}^{\wedge} 2$ & 0.930 & 0.425 & 0.213 & 0.009 & 0.0002 & 0.001 & 0.001 \\
\hline & coef. & -1.311 & -1.403 & -0.847 & -0.087 & -0.008 & 0.009 & 0.008 \\
\hline & NW & 0 & 0 & 0.003 & 0.313 & 0.910 & 0.846 & 0.674 \\
\hline & $\mathrm{HH}$ & 0 & 0 & 0.041 & 0.449 & 0.922 & 0.859 & 0.700 \\
\hline \multirow[t]{4}{*}{$\mathrm{P} / \mathrm{IP}$} & $\mathrm{R}^{\wedge} 2$ & 0.239 & 0.639 & 0.454 & 0.118 & 0.065 & 0.028 & 0.012 \\
\hline & coef. & -0.605 & -1.738 & -1.194 & -0.272 & -0.126 & -0.053 & -0.017 \\
\hline & NW & 0 & 0 & 0 & 0.001 & 0.003 & 0.047 & 0.096 \\
\hline & $\mathrm{HH}$ & 0 & 0 & 0 & 0.018 & 0.015 & 0.036 & 0.071 \\
\hline \multicolumn{2}{|c|}{ Estonia (TALSE) } & $10 \mathrm{Y}$ & $5 \mathrm{Y}$ & $3 \mathrm{Y}$ & $1 \mathrm{Y}$ & $6 \mathrm{M}$ & $3 \mathrm{M}$ & $1 \mathrm{M}$ \\
\hline \multirow[t]{4}{*}{$\mathrm{P} / \mathrm{GDP}$} & $\mathrm{R}^{\wedge} 2$ & 0.803 & 0.725 & 0.432 & 0.117 & 0.038 & 0.012 & 0.002 \\
\hline & coef. & -0.934 & -1.423 & -0.962 & -0.309 & -0.122 & -0.044 & -0.01 \\
\hline & NW & 0 & 0 & 0 & 0 & 0.039 & 0.258 & 0.477 \\
\hline & $\mathrm{HH}$ & 0 & 0 & 0 & 0.011 & 0.077 & 0.242 & 0.435 \\
\hline \multirow[t]{4}{*}{$\mathrm{P} / \mathrm{IP}$} & $\mathrm{R}^{\wedge} 2$ & 0.569 & 0.581 & 0.299 & 0.069 & 0.017 & 0.004 & 0.0005 \\
\hline & coef. & -0.679 & -1.038 & -0.639 & -0.185 & -0.063 & -0.019 & -0.003 \\
\hline & NW & 0 & 0 & 0 & 0.008 & 0.152 & 0.503 & 0.717 \\
\hline & $\mathrm{HH}$ & 0 & 0 & 0.002 & 0.055 & 0.213 & 0.463 & 0.635 \\
\hline \multicolumn{2}{|c|}{ Russia (TALSE) } & $10 \mathrm{Y}$ & $5 \mathrm{Y}$ & $3 \mathrm{Y}$ & $1 \mathrm{Y}$ & $6 \mathrm{M}$ & $3 \mathrm{M}$ & $1 \mathrm{M}$ \\
\hline \multirow[t]{4}{*}{$\mathrm{P} / \mathrm{GDP}$} & $\mathrm{R}^{\wedge} 2$ & 0.985 & 0.721 & 0.832 & 0.337 & 0.171 & 0.078 & 0.027 \\
\hline & coef. & -0.957 & -0.883 & -1.365 & -0.574 & -0.290 & -0.126 & -0.036 \\
\hline & NW & 0 & 0 & 0 & 0 & 0 & 0.002 & 0.047 \\
\hline & $\mathrm{HH}$ & 0 & 0 & 0 & 0,004 & 0,005 & 0 & 0.002 \\
\hline \multirow[t]{4}{*}{$\mathrm{P} / \mathrm{IP}$} & $\mathrm{R}^{\wedge} 2$ & 0.955 & 0.711 & 0.476 & 0.160 & 0.033 & 0.012 & 0.002 \\
\hline & coef. & -0.857 & -0.642 & -0.402 & -0.172 & -0.064 & -0.025 & -0.005 \\
\hline & NW & 0 & 0 & 0 & 0.016 & 0.373 & 0.545 & 0.714 \\
\hline & $\mathrm{HH}$ & 0 & 0 & 0 & 0.061 & 0.465 & 0.585 & 0.726 \\
\hline
\end{tabular}


Pobrane z czasopisma Annales H - Oeconomia http://oeconomia.annales.umcs.pl

Data: 26/04/2023 14:16:36

Cont. Table 2.

\begin{tabular}{|c|c|c|c|c|c|c|c|c|}
\hline \multicolumn{2}{|c|}{ Croatia (CROBEX) } & \multirow{2}{*}{$\begin{array}{r}10 \mathrm{Y} \\
0.967\end{array}$} & \multirow{2}{*}{$\begin{array}{r}5 \mathrm{Y} \\
0.692\end{array}$} & \multirow{2}{*}{$\begin{array}{r}3 \mathrm{Y} \\
0.566\end{array}$} & \multirow{2}{*}{$\begin{array}{r}1 \mathrm{Y} \\
0.210\end{array}$} & \multirow{2}{*}{$\begin{array}{r}6 \mathrm{M} \\
0.091\end{array}$} & \multirow{2}{*}{$\begin{array}{r}3 \mathrm{M} \\
0.034\end{array}$} & \multirow{2}{*}{$\begin{array}{r}1 \mathrm{M} \\
0.008\end{array}$} \\
\hline $\mathrm{P} / \mathrm{GDP}$ & $\mathrm{R}^{\wedge} 2$ & & & & & & & \\
\hline & coef. & -1.004 & -1.332 & -1.176 & -0.436 & -0.192 & -0.074 & -0.018 \\
\hline & NW & 0 & 0 & 0 & 0.036 & 0.138 & 0.258 & 0.380 \\
\hline & $\mathrm{HH}$ & 0 & 0 & 0 & 0.133 & 0.280 & 0.367 & 0.482 \\
\hline \multicolumn{2}{|c|}{ Bulgaria (SOFIX) } & $10 \mathrm{Y}$ & $5 \mathrm{Y}$ & $3 \mathrm{Y}$ & $1 \mathrm{Y}$ & $6 \mathrm{M}$ & $3 \mathrm{M}$ & $1 \mathrm{M}$ \\
\hline \multirow[t]{4}{*}{$\mathrm{P} / \mathrm{GDP}$} & $\mathrm{R}^{\wedge} 2$ & 0.955 & 0.812 & 0.485 & 0.157 & 0.057 & 0.019 & 0.004 \\
\hline & coef. & -0.860 & -1.561 & -0.974 & -0.300 & -0.114 & -0.040 & -0.008 \\
\hline & NW & 0 & 0 & 0 & 0.034 & 0.124 & 0.259 & 0.473 \\
\hline & $\mathrm{HH}$ & 0 & 0 & 0 & 0.133 & 0.256 & 0.343 & 0.492 \\
\hline \multicolumn{2}{|c|}{ Romania (BET) } & $10 \mathrm{Y}$ & $5 \mathrm{Y}$ & $3 Y$ & $1 \mathrm{Y}$ & $6 \mathrm{M}$ & $3 \mathrm{M}$ & $1 \mathrm{M}$ \\
\hline \multirow[t]{4}{*}{$\mathrm{P} / \mathrm{GDP}$} & $\mathrm{R}^{\wedge} 2$ & 0.672 & 0.744 & 0.492 & 0.252 & 0.141 & 0.074 & 0.027 \\
\hline & coef. & -0.866 & -1.525 & -1.233 & -0.542 & -0.262 & -0.120 & -0.036 \\
\hline & NW & 0 & 0 & 0 & 0.002 & 0.010 & 0.030 & 0.060 \\
\hline & $\mathrm{HH}$ & 0 & 0 & 0 & 0.027 & 0.054 & 0.067 & 0.090 \\
\hline
\end{tabular}

Source: Authors' own study.

The regression results for cumulative excess returns against P/GDP and P/IP ratios and for total returns reveal similar regularities: decreasing explained part of variability and the statistical significance of the regression coefficients (increasing $p$-value) as the time horizon of these returns grows shorter. In the case of countries such as the Czech Republic, Hungary, Lithuania, Estonia, Romania, and Poland, the relationships proved slightly weaker in the $R^{2}$ categories (except for 10-year returns) compared with the previous study presented in Table 1, probably because of the price-output ratio being also negatively correlated with the future interest rates. Overall, however, the prognostic properties of the analysed ratios proved surprisingly good for both excess returns (thus confirming the findings of the earlier study) and total returns, especially for the long-horizon ones (from 3 years upwards).

\section{Conclusions}

The research presented in the paper has shown that the price-output ratio explains a large part of the variations in the future stock returns in most Central and Eastern European countries and, to a slightly lesser extent, also in excess returns. It has also been found that the predictability of stock returns and excess returns improves with the length of the time horizon, a finding consistent with the research results for highly developed countries. The practical meaning of these results is that the price-to-GDP and price-to-industrial production ratios can be a useful element of the models constructed by investors and analysts to predict stock market returns and risk premiums. 
A natural extension of future research in this area seems the use of more sophisticated statistical techniques like those used in sample studies. It would be certainly interesting to know if a high in-sample $R^{2}$ also indicates out-of-sample predictability. A major limitation to this type of research in many countries is the unavailability of sufficiently long time series.

\section{References}

Ang, A., \& Bekaert, G. (2007). Stock return predictability: Is it there? Review of Financial Studies, 20(3), 651-707.

Bansal, R., \& Yaron, A. (2004). Risks for the long run: A potential resolution of asset pricing puzzles. Journal of Finance, 59, 1481-1509.

Campbell, J., \& Shiller, R.J. (1988). The dividend-price ratio and expectations of future dividends and discount factors. Review of Financial Studies, 1(3), 195-228.

Campbell, J.Y., \& Cochrane, J.H. (1999). By force of habit: A consumption-based explanation of aggregate stock market behaviour. Journal of Political Economy, 107, 205-251.

Campbell, J., \& Shiller, R.J. (2001). Valuation ratios and the long-run stock market outlook: An update. Working Paper no. 8221, NBER.

Chang, Y.S., \& Pak, D.H. (2018). Warren Buffett value indicator vs. GDP size - is the relationship superlinear? International Journal of Economics and Business Research, 15(2), 223-235.

doi:10.2139/ssrn.2897317

Cochrane, J.H. (1991). Production-based asset pricing and the link between stock returns and economic fluctuations. Journal of Finance, 46, 207-234.

Cochrane, J.H. (2007). The dog that did not bark: A defense of return predictability. Review of Financial Studies, 21, 1533-1575.

Cochrane, J.H. (2011). Presidential address: Discount rates. Journal of Finance, 66(4), 1047-1108. doi:10.1111/j.1540-6261.2011.01671.x

Domian, D.L., \& Reichestein, W.R. (2009). Long-horizon stock predictability: Evidence and applications. The Journal of Investing, 18(3), 12-20.

Fama, E.F., \& French, K. (1988). Dividend yields and expected stock returns. Journal of Financial Economics, 22, 3-25.

Goyal, A., \& Welch, I. (2003). Predicting the equity premium with dividend ratios. Management Science, $49,639-654$.

Harri, A., \& Brorsen, B.W. (2009). The overlapping data problem. Quantitative and Qualitative Analysis in Social Sciences, 3(3), 78-115.

Hansen, L., \& Hodrick, R. (1980). Forward exchange rates as optimal predictors of future spot rates: An econometric analysis. Journal of Political Economy, 88(5), 829-853.

Hodrick, R.J. (1992). Dividend yields and expected stock returns: Alternative procedures for inference and measurement. Review of Financial Studies, 5(3), 357-386.

Indrayono, Y. (2019). Predicting returns with financial ratios: Evidence from Indonesian Stock Exchange. Management Science Letters, 9(11), 1901-1908. doi:10.5267/j.msl.2019.6.003

Keimling, N. (2016). Predicting stock market returns using the Shiller CAPE - an improvement towards traditional value indicators? doi:10.2139/ssrn.2736423

Kirby, C. (1997). Measuring the predictable variation in stock returns. Review of Financial Studies, 10(3), 579-630.

Lettau, M., \& Ludvigson, S. (2001). Consumption, aggregate wealth and expected stock returns. Journal of Finance, 56(3), 815-849. doi:10.1111/0022-1082.00347 
Lleo, S., \& Ziemba, W.T. (2019). Can Warren Buffett forecast equity market corrections? The European Journal of Finance, 25(4), 369-393. doi:10.1080/1351847X.2018.1521859

Nelson, C.R., \& Kim, M.J. (1993). Predictable stock returns: The role of small sample bias. Journal of Finance, 48, 641-661.

Newey, W.K., \& West, K.D. (1987). A simple, positive semi-definite, heteroskedasticity and autocorrelation consistent covariance matrix. Econometrica, 55(3), 703-708.

Rangvid, J. (2006). Output and expected returns. Journal of Financial Economics, 81(3), 595-624. doi:10.1016/j.jfineco.2005.07.010

Rapach, D.E., Wohar, M.E., \& Rangvid, J. (2005). Macro variables and international stock return predictability. International Journal of Forecasting, 21(1), 137-166. doi:10.1016/j.ijforecast.2004.05.004

Robertson, D., \& Wright, S. (2006). Dividends, total cash flow to shareholders, and predictive return regressions. The Review of Economics and Statistics, 88(1), 91-99.

Santos, T., \& Veronesi, P. (2006). Labor income and predictable stock returns. Review of Financial Studies, $19(1), 1-44$.

Sekuła, P. (2016). Strategia wartości - test na GPW w Warszawie. Annales Universitatis Mariae Curie-Sktodowska, sectio H-Oeconomia, 50(4), 414-421.

Shiller, R.J. (2014). Speculative asset prices. Cowles Foundation Discussion Paper, 1936. doi:10.2139/ssrn.2391284

Stambaugh, R.F. (1999). Predictive regressions. Journal of Financial Economics, 54, 375-421.

Trevino, R., \& Robertson, F. (2002). P/E ratios and stock market returns. Journal of Financial Planning, $15(2), 76-84$. 